\title{
CT FINDINGS OF AN ENDO-ORBITAL OSTEOMA PRODUCING PROPTOSIS AND THE OPTIC NERVE'S COMPRESSION
}

\section{Roberto Corona-Cedillo', Melanie-Tessa Saavedra-Navarrete2, Arturo Albrandt-Salmeron', Ernesto Roldan-Valadez 3,4}

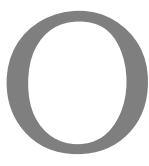

steoma is a benign bone tumour, with an incidence of $2 \%$ of all orbital tumours. Osteomas located in orbit remain asymptomatic until they reach a size that originates mass effect signs such as exophthalmos, diplopia, and unilateral blindness.

Materials and methods. In this case, a male patient presented to the emergency room with progressive proptosis, worsening headaches, and swelling of the left anterior periorbital and frontal sinus region one year after the beginning of the symptoms.

Results. Imaging studies revealed a hyperdense mass in the left orbital floor displacing the left globe superiorly and anteriorly with the optic nerve's compression.

Conclusion. Osteoma may represent an emergency in the long term when left untreated; it may destruct the eye due to direct pressure on the optic nerve and disturbance of the ocular blood supply.

Keywords: orbital osteoma; proptosis; mass effect; optic nerve.

Corresponding author: Ernesto Roldan-Valadez, e-mail: ernest.roldan@usa.net

For citation: Roberto Corona-Cedillo, Melanie-Tessa Saavedra-Navarrete, Arturo Albrandt-Salmeron, Ernesto Roldan-Valadez. CT findings of an endo-orbital osteoma producing proptosis and the optic nerve's compression. REJR 2021; 11(1):200-205. DOI: 10.21569/2222-7415-2021-11-1-200-205.

Received: $\quad 10.02 .21$

Accepted:

01.04.21

\section{КОМПЬЮТЕРНАЯ ТОМОГРАФИЯ ЭНАООРБИТААЬНОЙ ОСТЕОМЫ, ВЫЗЫВАЮЩЕЙ ПРОПТОЗ И КОМПРЕССИЮ ЗРИТЕАЬНОГО НЕРВА}

\section{Роберто Корона-Седи^ьо', Мелани-Тесса Сааведра-Наваррете2, Артуро Альбранлт-Салмерон ${ }^{1}$, Эрнесто Ро^Аан-Валалес 3,4}

стеома - доброкачественная опухоль костей, в 2\% скучаев встречающаяся в области орбиты. Остеомы, расположенные в орбите, остаются бессимптомными до тех пор пока не достигнут размера, вызывающего такие признаки объемного обрзования, как экзофтальм, диплопия и односторонняя слепота.

Материалы и методы. Представцено клиническое наблюдение пациента, мужчины, который обратился в отдемение неотложной помощи с прогрессирующим проптозом, усимением головных бомей и отеком мевой передней периорбитальной области и области мобного синуса через год после появмения первых симптомов.

Результаты. Методы мучевой диагностики выявики гиперденсное образование в обасти дна мевой орбиты, смещающее мевое глазное яблоко кверху и кпереди, с компрессией зрительного нерва.

Вывод. Остеома орбиты может представлять опасность в долгосрочной перспективе, если вовремя не провести соответствующее лечение, так как остеома может вызвать повреждение глазного яблока из-за прямого давления на зрительный нерв и нарушения кровоснабжения гмаза.
1 - Departamento de Imagenologia, Salud Digna.

Mexico City, Mexico. 2 - Facultad de

Ciencias de la Salud, Universidad Anahuac Mexico.

Mexico City, Mexico. 3 - Hospital General de Mexico "Dr Eduardo Liceaga", Directorate of Research.

Mexico City, Mexico. 4 - I.M. Sechenov First Moscow State Medical University (Sechenov University), Department of Radiology.

Moscow, Russia.
1 - Отдел мучевой диагностки, Салюд Дигна.

г. Мехико, Мексика. 2 - Факультет медицинских наук Мексиканского университета Анауак.

г. Мехико, Мексика.

3 - ГАавный госпиталь Мексики "Доктор Эдуардо Аисеага". г. Мехико, Мексика. 4 - Первый Московский государственный медицинский университет им. И.М. Сеченова (Сеченовский университет). г. Москва, Россия.

КАючевые слова: остеома орбиты, проптоз, массовый эффект, оптический нерв. 
Контактный автор: Эрнесто Роцдан-Валадес, e-mail: ernest.roldan@usa.net

Для иитирования: Роберто Корона-Седильо, Мелани-Тесса Сааведра-Наваррете, Артуро Альбрандт-Салмерон, Эрнесто Ролдан-Валадес. Компьютерная томография эндоорбитальной остеомы, вызывающей проптоз и компрессию зрительного нерва. REJR 2021; 11(1):200-205. DOI: 10.21569/2222-7415-2021-11-1-200-205.
Статья получена:
10.02.21
Статья принята:
01.04.21

\section{I}

\section{ntroduction.}

Primary bone tumours constitute up to $2 \%$ of all orbital neoplasia [1]. Osteomas are benign, slow-growing, bone-forming tumours involving craniofacial bones [2]. Primary orbital osteomas are rare; endo-orbital osteoma most frequently originates from a secondary orbital extension of the paranasal sinuses [3]. Up to seven different types of orbital osteoma have been reported [4]. Generally, osteomas are asymptomatic or incidentally discovered; a computed tomography $(\mathrm{CT})$ scan is the imaging modality of choice for diagnosis [3, 5]. This case is relevant because it describes an unusual case of a young adult with primary orbital osteoma associated with eye compression. During the past ten years, approximately 15 case reports have been published.

\section{Case Report.}

A 36-year-old man attended the emergency room complaining of progressive proptosis, worsening headaches, and ocular pain. During the physical examination, he presented left eye movement limitations associated with diplopia and pressure-like sensation. Swelling that involved the left anterior periorbital and frontal sinus region was present; the patient observed this sign during last year. He also presented a downward deviation and limitations of lateral and vertical gaze. No papilledema or optic atrophy was detected on fundoscopic examination.

Computed tomography revealed a hyperdense frontal mass of the left orbital floor displacing the left globe inferiorly and displacing the orbital soft tissues superiorly (Fig. 1).

Besides, severe anterior dislocation of the left eye, the optic nerve's compression, and the right medial rectus muscle were seen (Fig. 2).

The imaging features of the lesion were suggestive of osteoma. The patient was referred to the neurosurgery and ophthalmology departments where the diagnosis was confirmed and scheduled follow-up.

\section{Discussion.}

Epidemiology.

Osteomas are benign, slow-growing tumours; orbital involvement usually results from invasion from adjacent sinuses, with an incidence ranging from $0.9 \%$ to $5.1 \%$; primary orbital involvement is infrequent. These tumours are commonly small and asymptomatic; only $5 \%$ of cases become symptomatic or require surgery. Most osteomas are diagnosed during the fourth and fifth decades of life. There is a slight preference for males $[3,6]$.

\section{Mass effect.}

Osteomas prevail silent until they reach a specific size. Lesion within the orbit can cause a variety of ocular anomalies secondary to mass effects, such as exophthalmos, diplopia, swelling, amaurosis, and acquired Brown syndrome. In exceptional scenarios, the tumour may grow intracranially and originate neurological complications $[6,7]$.

Structure compression.

The orbit is a cavity that contains many structures in a relatively narrow space; when osteoma is present, it commonly displaces extraocular muscles, presenting as diplopia and eye movement impairment. Additionally, the globe is markedly compressed, causing disk oedema, ophthalmic vein compression, and choroidal folds that will eventually cause optic atrophy and visual loss. Osteoma may represent an emergency in the long term because, if left untreated, they may destruct the eye due to direct pressure on the optic nerve and disturbance of the ocular blood supply, manifesting as unilateral blindness [8].

Imaging diagnosis.

Radiography is the basis of osteoma diagnosis; many times, it is the first imaging method to identify the tumour. Osteoma manifests as a radiopaque lesion with a nidus with a radiolucent centre enveloped by dense sclerosis [5].

A CT scan is the imaging modality of choice; it allows us to determine the tumour's anatomic position and its extensions precisely [5]. Osteomas appear as highly circumscribed osteoblastic masses. They conform to the internal contour of the bone wall and may have an irregular bulging surface. The bone window reveals a central trabecular area with a dense sclerotic periphery [1].

With magnetic resonance imaging (MRI), 


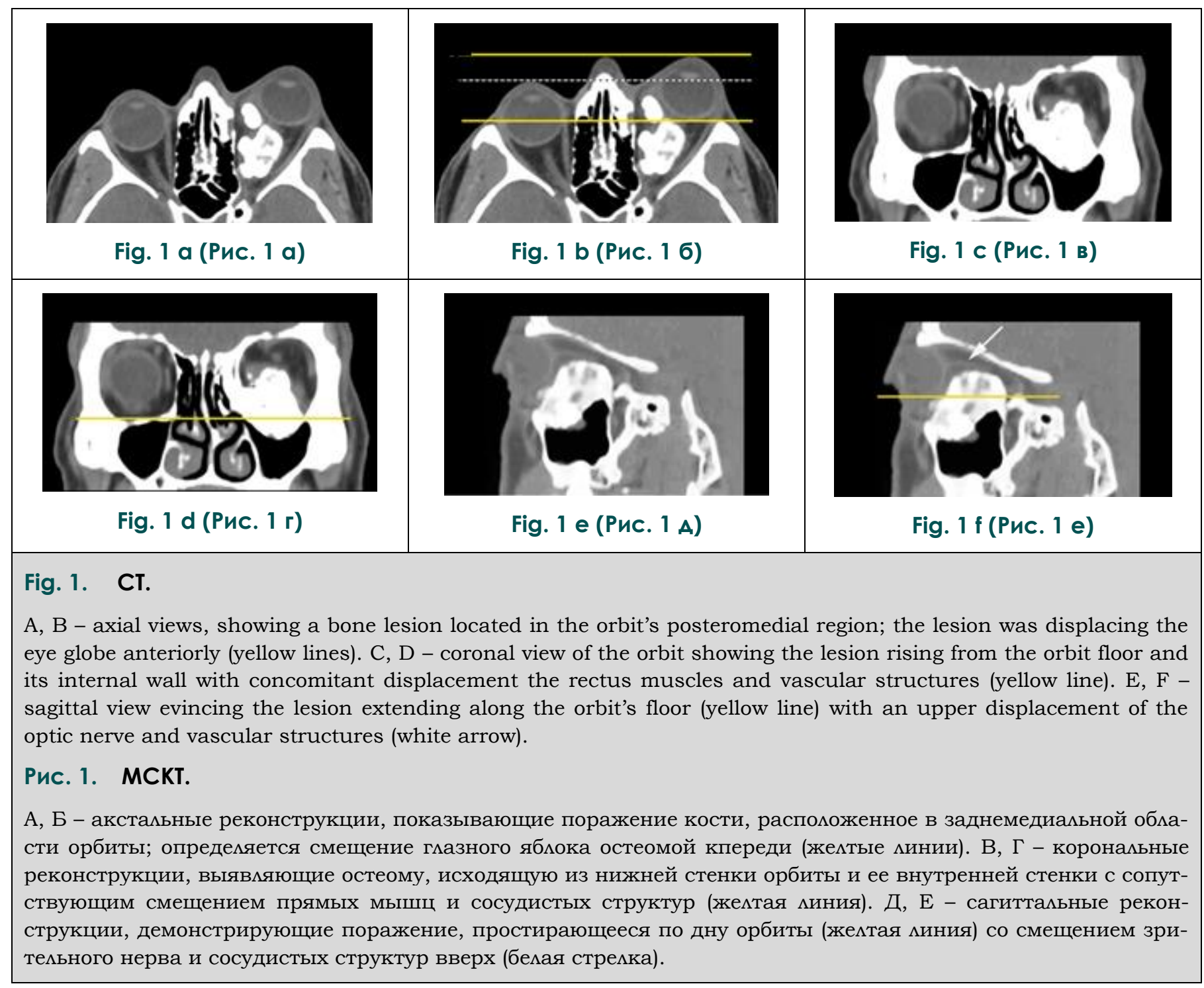

findings depend on the amounts of nidus calcification, fibrovascular zone size, sclerosis, and bone oedema; the lesion's signal void peripheral zone may not be recognizable from the air in the sinuses, interfering with the evaluation of tumour extension. Besides, MRI shows optic nerve invasion and damage to local tissue. Additionally, a radionuclide bone scan may differentiate an active growing lesion from a stable one $[6,9]$.

Although it is rarely reported, it is possible to evaluate this lesion with ultrasound (US). The US depicts an irregular and incompressible mass without internal vascularity. The anterior surface is very dense with excellent attenuation of sound, while the posterior surface has a characteristic sound attenuation. The orbital fat is comparatively less compared to the healthy orbit or sinus [10]. Table 1 presents a summary of the findings obtained with imaging techniques most commonly used in orbital osteoma.

Complications before treatment.

Serious complications have reported intracranial pneumatocele, pneumocephalus, meningitis, subdural abscesses and compressive neuropa- thies [11].

\section{Treatment.}

There are traditional two modalities of treatment: for tumour localized close to the optic nerve, total or subtotal surgical resection is done immediately; for asymptomatic cases, especially in elderly patients, the initial treatment consists of observation and follow up with periodic imaging controls considering the slow growth pattern of the osteoma. External surgical approaches include coronal, transcaruncular, tranconjunctival, and transblepharoplasty incisions [12, 13]. The most appropriate method is selected according to location, tumour volume, anatomical situation, and sinus extension [14]. Table 2 presents a summary of the most common surgical approaches to orbital osteoma.

Recent studies have evinced the efficacy and safety of percutaneous CT-guided cryoablation of osteoid osteoma at different sites [15]. The technique known as Magnetic resonance-guided focused ultrasound (MRgFUS), that was initially used in the ablation of uterine fibroids, has reported complete clinical success observed in $90 \%$ 


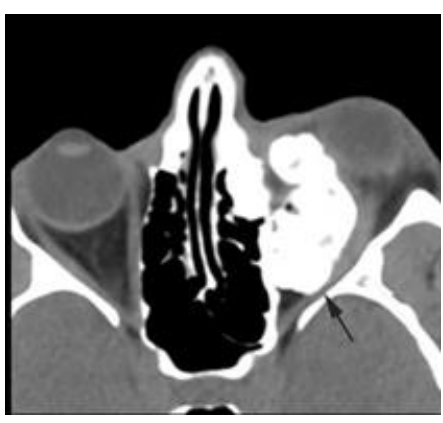

Fig. 2 a (Рис. 2 a)

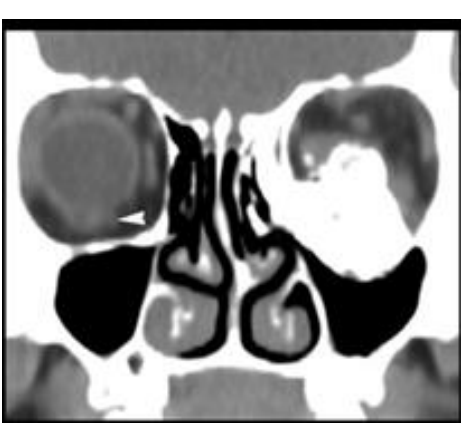

Fig. 2 b (Рис. 2 б)

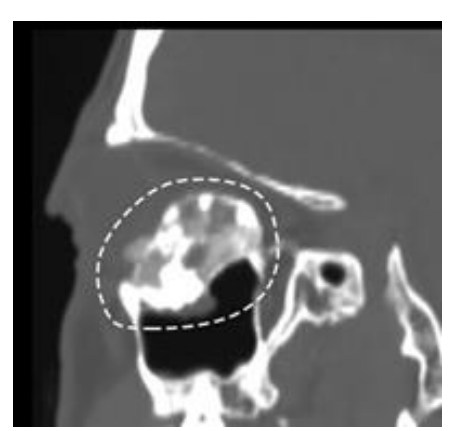

Fig. 2 с (Pис. 2 в)

\section{Fig. 2. $\quad \mathrm{CT}$, multiplanar reconsructions.}

A - axial view, showing the bone lesion in the left orbit displacing the globe laterally and causing proptosis with compression of the medial rectus muscle and the optic nerve (black arrow). B - coronal view, depicts the orbital wall's deformation and compression of inferior rectus muscle (white arrowhead). C - sagittal view of the orbit with a soft-tissue window displays the lesion's heterogenous bone composition (white ellipse).

\section{Рис. 2. К К, мультипланарные реконструкции.}

А - аксиальная реконтрукция, показывающий поражение кости мевой орбиты, смещающее глазное яблоко матерально и вызывающее проптоз со сжатием медиальной прямой мышцы и зрительного нерва (черная стрелка). Б - корональная реконструкция, демонстрирующая деформацию стенки орбиты и компрессию нижней прямой мышцы (белая стрелка). В - сагиттальная реконструкция, орбита, мягкотканное окно, выявмяется неоднородная стурктура остеомы (белый эмиипс).

\begin{tabular}{|c|l|}
\hline \multicolumn{2}{|c|}{ Table No1. Summary of the findings obtained with imaging techniques most commonly } \\
used in orbital osteoma. \\
\hline Imaging Modality & $\begin{array}{l}\text { F radiopaque lesion with a nidus which has a radiolucent centre enveloped by dense } \\
\text { sclerosis [5]. }\end{array}$ \\
\hline Radiography & $\begin{array}{l}\text { Circumscribed osteoblastic masses conform to the bone's internal wall and may have } \\
\text { an irregular bulging surface [1, 5]. }\end{array}$ \\
\hline CT & Trabecular central area with a dense sclerotic periphery [1]. \\
\hline CT-Bone window & $\begin{array}{l}\text { Imaging findings depend on calcification, fibrovascular zone, sclerosis, and oedema to } \\
\text { show optic nerve invasion and local tissue damage [6, 9]. }\end{array}$ \\
\hline Radionuclide bone scan & It can discriminate against an active lesion from a stable one [9]. \\
\hline Ultrasound & $\begin{array}{l}\text { Irregular and incompressible mass without internal vascularity. } \\
\text { Orbital fat is less compared to the healthy orbit [10]. }\end{array}$ \\
\hline
\end{tabular}

of cases of non-spinal osteoid osteoma [16-18]. However, its use has still not been reported for orbital osteomas.

Post-surgical complications.

They include recurring frontal sinusitis, iatrogenic paralysis of the IV cranial pair, postoperative frontal sinusitis with bone resorption in tardive phase and, eventually, loss of the anterior wall of the frontal sinus [19].

Follow-up.

Because osteomas have a slow growth rate of (average $1.6 \mathrm{~mm} /$ year), patients should be monitored for recurrence with annual clinical exams and biannual imaging with radiograph or $\mathrm{CT}$.
Once clinical and radiographic stability is reached after at least three to five years, imaging can be reserved only for new symptoms [3, 9].

Differential diagnosis.

Osteoblastoma is usually a central differential diagnostic consideration; other benign lesions include fibrous dysplasia and ossifying fibroma [20]. Osteoblastoma radiographically appears as a lytic and blastic mass with a peripheral ring of sclerotic bone and internal mineralization lesions $[6,21,22]$. Another differential diagnosis is fibrous dysplasia, and its CT findings usually show a homogenous ground-glass appearance. An ossifying fibroma is observed as a defined mass with 
Table №1. Indications of surgical approach for orbital osteoma surgery.

\begin{tabular}{c|l} 
Type of approach & \multicolumn{1}{c}{ Indications } \\
\hline Transconjunctival inferior fornix & Inferior orbital lesions \\
\hline $\begin{array}{c}\text { Anterior orbitotomy by lateral } \\
\text { canthotomy with swinging lower } \\
\text { eyelid }\end{array}$ & Provides exposure to inferior anterior orbital lesions \\
\hline Upper eyelid crease incision & Superior lesions \\
\hline Coronal incision & $\begin{array}{l}\text { Extensive lesions may require wider exposure, requiring reconstruction for optimal } \\
\text { functional and cosmetic result }\end{array}$ \\
\hline Transcaruncular & Superomedial osteomas \\
\hline
\end{tabular}

osteoblastic and osteolytic areas surrounded by a thin sclerotic margin [20, 22].

Conclusions.

Despite orbital osteoma is considered a benign condition, with a conservative attitude, preferred to asymptomatic osteomas; readers should be aware of the need to perform periodic control of

\section{References:}

1. Selva D, White VA, O'Connell JX, Rootman J. Primary bone tumors of the orbit. Surv Ophthalmol. 2004; 49 (3):328-342. doi:10.1016/j.survophthal.2004.02.011

2. McHugh JB, Mukherji SK, Lucas DR. Sino-orbital osteoma: a clinicopathologic study of 45 surgically treated cases with emphasis on tumors with osteoblastoma-like features. Arch Pathol Lab Med. 2009; 133 (10):1587-1593. doi:10.1043/1543-2165133.10.1587

3. Wei LA, Ramey NA, Durairaj VD, Ramakrishnan VR, Cruz AV, Dolman PJ, Lucarelli MJ. Orbital osteoma: clinical features and management options. Ophthalmic Plast Reconstr Surg. 2014; 30 (2):168-174. doi:10.1097/IOP.0000000000000039

4. Afghani T, Mansoor H. Types of orbital osteoma - a descriptive analysis. Orbit. 2018; 37 (1):3-8. doi:10.1080/01676830.2017.1353106

5. Muderris T, Bercin S, Sevil E, Kiris M. Endoscopic removal of a giant ethmoid osteoma with orbital extension. Acta Inform Med. 2012; 20 (4): 266-268. doi:10.5455/aim.2012.20.266-268

6. McCann JM, Tyler D, Foss RD. Sino-Orbital Osteoma With Osteoblastoma-Like Features. Head Neck Pathol. 2015; 9 (4):503-506. doi:10.1007/s12105-015-0613-5

7. Nielsen GP, Rosenberg AE. Update on bone forming tumors of the head and neck. Head Neck Pathol. 2017; 1 (1):87-93. doi:10.1007/s12105-007-0023-4

8. Mansour AM, Salti H, Uwaydat S, Dakroub R, Bashshour Z. Ethmoid sinus osteoma presenting as epiphora and orbital cellulitis: case report and literature review. Surv Ophthalmol. 1999; 43 (5):413-426. doi:10.1016/s0039-6257(99)00004-1

9. Sanchez Burgos R, González Martín-Moro J, Arias Gallo J, Carceller Benito F, Burgueño García M. Giant osteoma of the ethmoid sinus with orbital extension: craniofacial approach and orbital reconstruction. Acta Otorhinolaryngol Ital. 2013; 33 (6):431-434

10. Alameddine RM, Mansour AM, Kahtani E. Review of choroidal osteomas. Middle East Afr J Ophthalmol. 2014; 21 growth using serial, contemporary imaging techniques. If there is significant growth or intracranial or orbital extension or facial deformities, the attitude should become more aggressive, consisting of surgical removal using open or endoscopic techniques.

(3):244-250. doi:10.4103/0974-9233.134686

11. Jack LS, Smith TL, Ng JD. Frontal sinus osteoma presenting with orbital emphysema. Ophthalmic Plast Reconstr Surg 25. 2009; (2):155-157. doi:10.1097/IOP.Ob013e31819aaf14

12. Merritt H, Yin VT, Pfeiffer ML, Wang WL, Sniegowski MC, Esmaeli B. Treatment Challenges with Benign Bone Tumors of the Orbit. Ocul Oncol Pathol. 2015; 1 (2):111-120. doi:10.1159/000368651

13. Miman MC, Bayindir T, Akarcay M, Erdem T, Selimoglu E. Endoscopic removal technique of a huge ethmoido-orbital osteoma. J Craniofac Surg. 2009; 20 (5):1403-1406. doi:10.1097/SCS.Ob013e3181aee30e

14. Karbassi E, Arabi Mianroodi A, Shamsadini A. Orbital Extension of a Giant Ethmoidal Sinus Osteoma in a 30-Year-old Female. Iran J Otorhinolaryngol. 2013; 25 (71):119-122

15. Meng L, Zhang X, Xu R, Wu B, Zhang X, Wei Y, Li J, Shan $H$, Xiao Y. A preliminary comparative study of percutaneous $C T$ guided cryoablation with surgical resection for osteoid osteoma. PeerJ. 2021; 9:e10724. doi:10.7717/peerj.10724

16. Vazquez-Lamadrid J, Fernandez-de Lara Y, CarrascoChoque A, Romero-Trejo C, Cosme-Labarthe J, Roldan-Valadez E. Principles and technique of magnetic resonance guided focused ultrasound surgery (MRgFUS) in the treatment of uterine fibroids. Gac Med Mex. 2011; 147 (4): 333-341

17. Carrasco-Choque AL, Lara YF, Vivas-Bonilla I, Romero-Trejo $C$, Villa AR, Roldan-Valadez E. Perfusion volume correlates, percentage of involution, and clinical efficacy at diverse follow-up survey times after MR-guided focused ultrasound surgery in uterine fibroids: first report in a Mexican mestizo population. Eur Radiol. 2015; 25 (10): 2905-2912. doi:10.1007/s00330-0153707-2

18. Geiger D, Napoli A, Conchiglia A, Gregori LM, Arrigoni F, Bazzocchi A, Busacca M, Moreschini O, Mastantuono M, Albisinni U, Masciocchi C, Catalano C. MR-guided focused ultrasound (MRgFUS) ablation for the treatment of nonspinal osteoid osteo- 


\section{RUSSIAN ELECTRONIC JOURNAL OF RADIOLOGY}

ma: a prospective multicenter evaluation. J Bone Joint Surg Am. 2014; 96 (9): 743-751. doi:10.2106/JBJS.M.00903

19. Blanco Dominguez I, Oteiza Alvarez AV, Martinez Gonzalez LM, Moreno Garcia-Rubio B, Franco Iglesias G, Riba Garcia J. Frontoethmoidal osteoma with orbital extension. A case report. Arch Soc Esp Oftalmol. 2016; 91 (7): 349-352. doi:10.1016/j.oftal.2016.01.025

20. Yazici Z, Yazici B, Yalcinkaya U, Gokalp G. Sino-orbital osteoma with osteoblastoma-like features: case reports. Neuroradi- ology. 2012; 54 (7):765-769. doi:10.1007/s00234-011-0973-9 21. Kashkouli MB, Khalatbari MR, Yahyavi T, Borghei Razavi H, Shayanfar N, Parvaresh MM. Primary endo-orbital osteoid osteoma. Orbit. 2008; $27 \quad$ (3): $211-213$. doi:10.1080/01676830802009630

22. Strong EB, Tate JR, Borys D. Osteoid osteoma of the ethmoid sinus: a rare diagnosis. Ear Nose Throat. 2012; J 91 (5): E19-20. doi:10.1177/014556131209100519. 